the ordinary type are seen in the new specimen; but $I$ had to add " the body chamber and the last few septal chambers only [those which are distorted] being preserved in association." This is now no longer true, but the remainder of my description was entirely based on the probability, not to say the certainty, of such a specimen being ultimately found. It runs, "The earlier septa are of the ordinary kind, with very little convexity and the siphuncle is excentric, in some of large size ... The last few chambers are distorted and their dorsal portions are seldom seen." These dorsal portions, as in the specimen figured by Barrande (Syst. Sil. de la Bohême, vol. ii. p. 513), are well shown in the new specimen. I arrived at the same conclusion as Professor Lindström-that the Ascoceras "is by no means the simplest form of Cephalopod, but the most abnormal," and included it with Poterioceras and others in the group Inflati, the genus being characterized by having its "later septa distorted." The group is said to diverge from the Conici, i.e. the Orthocerata, etc., and to be remarkable for the loss of the early septa.

It is satisfactory that in all these points the new specimens from Gothland confirm the previous observations. J. F. BLAkr.

\title{
THE MONIAN SYSTEM,
}

Sir,-I feel greatly indebted to Dr. Callaway for introducing the Munian System to the notice of your readers. It was throngh his advice I went to Anglesey, and he naturally takes a fatherly interest in the result.

There are, however, certain points in his "Notes" which call for explanation or reply.

1. I am happy to recognize that Dr. Callaway, in 1887, quite independently of my observations, came to the conclusion that the hornblende-schists were of igneous origin, notwithstanding that such a conclusion entirely overthrew bis reading of the succession in the "gneissic series." I must even confess that he is bolder than I am, for my statement that these schists are igneous, is made in fear and trembling; for though I am forced to it by the stratigraphy, I know it would have been laughed at a few years ago. Nor can I get as far as "foliated felsites," those so considered by Dr. Callaway being compressed and indurated examples of the ordinary mica-schists of the district.

2. As to Parys Mountain, there are two other writers' opinions to consider besides Dr. Callaway's.

3. As to the Llanfechell Grit. I acknowledge it would be of some importance if it could be shown that any large part of the upper portion of the series was made up of fragments of the lower ; but after all the Llanfechell Grits are merely subordinate bands in a long series, and there are no conglomerates in association with them, so that at best any included fragments would be poor evidence. Moreover, it seems quite common in these old rocks, for the earlier deposits to be rapidly altered and to contribute to the later. Thus the con- 
glomerate of Bull Bay is made of the underlying quartz rock. The fragments in the "agglomerates" or "conglomerates " of Llangefni are like some of the neighbouring rocks, the Bangor beds are full of fragments of rocks very similar to other parts of the same series, and the conglomerate of Moel Tryfaen is largely composed of the immediately preceding Cambrian slates. I do not, therefore, give much weight to any argument from such a grit. I only dealt with it because it was confessedly at first the only argument for there being two groups of Precambrian rocks in Anglesey. If the rock is discussed, I have to say that of course Prof. Bonney's description is accurate. The fragments do "much resemble some of the finergrained schists of Anglesey;" but they resemble those parts which have been entirely re-formed; such entire re-formation occurs sometimes in bands parallel to the lamination, sometimes in veins crossing it, and is not confined to the older part of the series, but affects many other parts. The veins, like the rest of the rock, have formed under a pressure that has induced an orientation of the micaceous ingredient. We cannot, therefore, identify the fragments with any definite rock.

4. The rocks near Llyn Irefwll. In this case, again, I should have said nothing except for the stress Dr. Callaway lays upon the locality. I twice failed to find the exact spot referred to, though the whole structure of the surrounding rocks seemed clear. Only by the minutest directions was I able to find a spot where some slaty-looking rock contained fragments of granite, and seems continuous with the diabase which forms part of several bosses. All these figure as "slate" in Dr. Callaway's paper. Several slides have been examined and prove to be diabase-hence "some of the slates of Dr. Callaway are diabase." Where the granitio fragments are found, this diabase has become more or less hornblendic, or dioritic-or it may be that the containing rock is a distinct one. In any case, fragments of granite are contained in a slaty-looking rock which is not a slate. They must also be contained in a true slate, since such is their matrix as described by Prof. Bonney; but this slate is certainly not the diabase ridge figured as Pebidian by Dr. Callaway. It is really not worth while pursuing the question any further.

5. With regard to the areas where there is a passage between Dr. Callaway's lower and upper groups, bis observations are rather special pleading, because he selects two places, nearly the only two, where the succession is confessedly broken by faults, and gives these as examples; whereas in both these places the supposed succession is stated to be entirely made out from what is observed abundantly elsewhere.

6. As to the applicability of the Monian system to other regions, it is obvious that our first business is to thoroughly understand the development of a series of rocks in the place where the connection of one part with another is most fally displayed, and such a place is Anglesey, where the succession and stratigraphy in many places is comparatively clear. It is a later work to correlate otber regions with the type, the probable result only being briefly indicated in my. 
paper. The reason for correlating the Longmynd rocks with the Upper Monian are, first, that they are certainly pre-Cambrian, especially since the discovery by Prof. Lapworth of the lowest Cambrian fauna in other rocks in the immediate neighbourhood, and, secondly, that the only certain fossils recorded from the Longmynd, Arenicolites didyma, are also recorded from the rocks of Bray Head. It is also to be noted that as the "Uriconian" is to a large extent volcanic, there need not be much of a gap between it and the "Longmyndian." By some curious effort of the imagination Dr. Callaway says "Uriconian and Malvernian are lumped together as Middle Monian," but I cannot find that I have anywhere mentioned the "Malvernian," as I know too little of that district and the descriptions are too discordant to make it safe even to venture upon a probability. It may not be Monian at all.

If Dr. Callaway has a fancy to call the different divisions of the Monian by names derived from other districts, there can be no objection, provided we first make sure of the correlation. I am perfectly satisfied with their all forming parts of a larger group or system-the Monian.

I may add that as these rocks have a quite distinct character from the true Hebridean, or the general type of gneisses, I was much delighted to find that so many foreign geologists, who visited Anglesey in September last, recngnized their resemblance to rocks of their several districts which occur immediately beneath their lowest fossiliferous horizons.

Dec., 1888.

\section{UNIFORMITY IN SCIENTIFIC BIBLIOGRAPHY.}

SIR,-Having been for some time engaged in preparing a bibliography of earthquake-literature, I can fully endorse the necessity of Mr. C. D. Sherborn's plea for uniformity in the quotation of abbreviated titles of scientific journals. The increasing number and importance of works of this class render this and other unsettled. points in bibliography worthy of attention and discussion; and I would venture to suggest that the British Association Committee on Zoological Nomenclature could find a useful successor in a Committee for securing Uniformity in Scientific Bibliography.

May I be allowed to offer here a few remarks on this subject?

Abbreviated Titles. - Besides a mere hap-hazard choice two courses are open in the selection of abbreviated titles.

(1) We may adopt that in use amongst the members of the Society issuing the journal, as "Phil. Trans." or "Comptes Rendus." Familiarity in a few cases and established custom are in favour of the retention of this system, but it has the obvious disadvantage of not representing at a glance the complete title of an unknown journal, for it omits the name of the society. Moreover, contractions founded on such words as "T'ransactions" or "Proceedings," common to a great number of societies, are objectionable.

(2) The abbreviations may be formed on a uniform plan from the full title of the journal. That adopted in the Geological Record 